\title{
The Impact of Arab Spring on the Political Future of the Muslim Brotherhood in the Middle East: Jordan as a Case Study
}

\author{
Dr. Abdelmahdi Alsoudi \\ Department of Sociology \\ University of Jordan, Amman, Jordan.
}

This research has been carried out during my sabbatical leave that was granted to me by the University of Jordan during 2014-2015 academic year.

\begin{abstract}
The Arab Spring has developed new political realities in the Arab World and paved the way for the surge of the Muslim Brothers, even enabling them to form short lived governments in Tunis and Egypt. The Muslim Brothers in Jordan, encouraged by these developments, took a leading role in the uprising but instead of participating in the political process, the movement adopted an extreme position and boycotted the 2010 and 2013 parliamentary elections. The movement today faces open confrontation with the regime and suffers from internal division and conflict. The disastrous outcome of the Arab Spring in Syria, Libya and Yemen, and the banning of the Muslim Brotherhood in Egypt, Saudi Arabia and UAE, has weakened the Muslim Brotherhood's political influence in the region in general and in Jordan in particular. The political future of the Muslim Brotherhood in Jordan and its political relevance depends on two factors; government's policy and the unfolding internal crisis within the movement. This paper argues that the Arab Spring has serious negative impact on the political future of the Muslim Brotherhood in Jordan and the movement needs serious efforts to restore its previous political role and influence in the country.
\end{abstract}

Keywords: Jordan Muslim Brotherhood, Islamic Action Front, Arab Spring, protests, Jordan uprising

\section{Introduction}

During the last four years, the Arab World faced a wave of uprisings which led to the overthrow of four Arab regimes in Tunisia, Egypt, Libya, and Yemen; created conflict and civil wars in Syria, Libya, Yemen and Iraq with less impact on Jordan, Morocco, the GCC and other Arab countries. The Arab Spring has thus, paved the way for some moderate Islamists to establish political parties, run and win parliamentary elections and even form governments in Tunisia and Egypt. It has also led to the appearance of new radical Islamists groups such as al-Nusrah, Daesh, and ISIS in Syria, Iraq, Libya and Ansar Allah (al-Hothies) in Yemen.

The impact of the Arab Spring on Jordan however, was less dramatic as the leadership in Jordan took several political steps to meet the people's demands and used soft power to manage and control the uprising. However, the Islamist movement in Jordan, inspired by the empowerment of the Muslim Brotherhood in Tunisia and Egypt, refused all governmental efforts and proposal to participate in the political process, and indeed boycotted the parliamentary elections of 2010 and 2013. Starting mid 2014, the fortunes of the Muslim Brotherhood in both 
Egypt and Tunisia were reversed as both movements lost political power. Most importantly, the Muslim Brotherhood in Egypt was banned and declared a terrorist organization in Egypt, Saudi Arabia and UAE. The chaos and civil wars in Syria, Yemen and Libya, the appearance of Daesh and ISIS in Syria and Iraq and the burning of the Jordanian pilot by ISIS in February 2015 has changed the Jordanians' attitudes towards the Muslim Brotherhood and other Islamic groups.

The Muslim Brothers' un-compromising position towards political participation; insisting on their extreme demands of fixing the political system and boycotting the parliamentary elections, has created serious internal conflict among its leadership and damaged its relationship with the regime. The movement first witnessed the appearance of the Zamzam Movement and later, the establishment of the "Society of Muslim Brotherhood in Jordan" which was immediately licensed by the government in April 2015. This is in addition to rivalries from other Islamic political parties and groups such as al-Wasat Party and other Salafist and Jihadist groups. These internal and external factors raised serious questions about the political future of the Muslim Brotherhood and its relatedness to Jordan's politics. The focus of this paper is to research the impact of the Arab Spring on the political future of the JMB and to answer the following question: to what extent did the position and action of the JMB weaken their support among the Jordanian people and how it affected their relationship with the regime? The impact of the Arab Spring on Islamists in Jordan provides an excellent case study in which to explore the future role of Islamist politics in Jordan and beyond.

\section{a. The Importance of the Study}

The radical position of the Muslim Brotherhood during the Arab Spring, especially its refusal to the government's proposals to participate in the political process, has damaged its traditionally good relationship with the regime in Jordan and created internal conflict among its leadership. This has resulted in a split of the movement into two rival groups; the old Muslim Brotherhood and the Society of Muslim Brotherhood in Jordan. This government move was interpreted by the old Muslim Brotherhood as a step to weaken their position in politics and society. Today, it faces serious challenge not only to its legal existence but also to its political future which is very important to the security and stability of the country. Therefore, this study deals with a very important issue - that is the impact of the Arab Spring on the political future of the Muslim Brothers which has far reaching consequences not only for the security and stability of Jordan but also for the entire region.

\section{b. Abbreviations and Acronyms}

ISIS- Islamic State in Iraq and Syria

HCCNOP- The Higher Committee for the Coordination of National Opposition Parties

IAF- Islamic Action Front

JMB- Muslim Brotherhood in Jordan

Hirak- The different uprising groups in Jordan 
Daesh - an off- spring of al-Qaeda originated in Iraq and then Syria

Jubhat al-Nusrah- a branch of al-Qaeda in Syria

IS- Islamic State

ISL- Islamic State in Syria and the Levant

Caliph- The head of the Islamic state

Caliphate- Islamic rule or governance

Al-Hothies- the Shiites group that led the uprising in Yemen

Shari' $\boldsymbol{a}$ law- the rules and regulations derived from Quran and Sunnah

\section{c. Study Objectives}

1. Analyzing Arab Spring dynamics and impact on the Middle East

2. Understanding responses of the Jordanian Regime to the Arab Spring

3. Understanding the effects of Arab Spring on the Muslim Brotherhood

4. Analyzing the relationship between the regime and the Muslim Brotherhood

5. Assessing the impact of the Arab Spring on the political future of the Muslim Brotherhood in Jordan

\section{d. Research Methodology and Design}

The goal of this study is to analyze the impact of the Arab Spring on the political future of the Muslim Brotherhood in Jordan and the region. It will use a combination of comparative and qualitative research methods to conduct analysis of the impact of the Arab Spring on the political future of the Muslim Brotherhood in the Middle East, with Jordan as a case study. It draws on a range of primary and secondary sources, including declarations, interviews, documents, reports, published books, and articles about the impact of the Arab Spring on the Muslim Brothers during 2011-2015. It compiled and analyzed many documents, decisions, laws and statements issued by the governments of the region and the Muslim Brotherhood.

In order to understand the different outcomes and impact of the Arab Spring on the Muslim Brotherhood in Jordan and the region, the study will compare and contrast the experience of the Muslim Brotherhood in Jordan and other Arab countries. It used eight variables to examine their effects on success or failure of the uprisings in both Jordan and Egypt. These are: 1. Elite unity; 2. Scale of protest; 3. The use of force; 4. Occupation of public places; 5. Responses to uprising demands; 6. Army intervention; 7. Population unity; 8. Uprising unity.

This study assumes that the presence of these variables indicates success while their absence indicates the failure of the regime in handling the uprising. The first variable is the elite unity which will be measured by determining if the elite broke up with the regime as negative while their unity and support are deemed as positive. The second variable is the scale of protest which will be determined as positive if the protest was massive while smaller scale will be deemed negative. The third variable is the use of force which will be measured and determined negative if force was used and positive if not. The fourth variable is occupation 
of public places which will be measured and determined as positive if occupation of public space took place while negative if it did not happen. The fifth variable is regime responses to the uprising demands which will be measured and considered positive if the regime met some of the protesters' demand while negative if it did not. The sixth variable is the army intervention which will be measured and considered positive if the army refused to intervene while negative if it intervened. The seventh variable is population unity, which will be measured and considered positive if the people fully supported the uprising while their division or lack of support will be taken as negative. The eighth variable is uprising unity, which will measure and consider the uprising unity as positive while their division will be considered as negative.

\section{Literature Review}

There have been many social movements throughout history that have dramatically changed societies such as the revolutions in Russia, France, USA, China, Europe, South America and the Middle East. They varied widely in their impact and ideologies as some of them have changed the socio-economic and political structures while others have worked to reform the existing sociopolitical system. However, despite all these differences among social movements, sociologists have distinguished many important similarities with regard to their causes and outcomes. ${ }^{1}$

Sociologists and social movements' experts introduced and used several theories to explain the causes and dynamics of social movements; among them the Resource Mobilization Theory which seeks to explain the emergence of social movements depending on the availability of resources such as knowledge, money, media, solidarity, and internal and external support. The theory argues that social movements develop when individuals with grievances are able to mobilize sufficient resources to take action. It assumes a link between resources available to social movement and its success or failure. ${ }^{2}$

However, the Resource Theory was later formally replaced by the Political Process Theory which emphasizes the role of political opportunities, mobilizing structures and framing processes, along with protest cycles. Charles Tilly asserts that the interaction between interests, organization and opportunity, explains the level of mobilization and collective action. He argues that social movements are rational attempts by disadvantaged people to mobilize collective political power to achieve their common goal or interest. ${ }^{3}$ McAdam argues that in order for individuals to participate in a movement, they must feel that the lack of the current political system to legitimacy and their participation could make a meaningful change in society. ${ }^{4}$ This is very useful for our analysis of the Arab Spring as the success of the uprisings in Tunisia and Egypt encouraged the initiation of similar movements throughout the Arab World.

The Contentious Politics Theory which was developed during the 1990s and the beginning of the 21st century by Sidney Tarrow, Charles Tilly, and Doug McAdam deals with the use of revolt, demonstrations, or even revolution to express grievances, or to change government policy. ${ }^{5}$ However, Fawaz Gerges 
used Contentious Politics Theory to analyze the complexities of the Arab uprisings without neglecting the connections between the people and other structural factors. ${ }^{6}$

The Four Stages Social Movement Theory argues that social movements grow through four stages which are: development, emergence, coalescence, bureaucratization and decline. ${ }^{7}$ This theory does not apply to the Arab uprisings as they have erupted and declined in a very short period of time. The other relevant theory is the Marxist' Theory of Class Relationships which argues that social movements grow out of basic social and economic relations, that peoples' participation in social movements is a rational activity, and that "revolutions are connected to the larger society." "However, because of its main focus on class conflict, its analysis has limited its explanatory power in traditional and classless societies like Arab societies where other political and religious factors play a significant role in the uprising.

The Social Movement Theory was used recently by Sean Lynch to draw comparison between successful and unsuccessful Arab uprisings by using seven variables. ${ }^{9}$ He examined and compared the two successful uprisings in Egypt and Tunisia, and three unsuccessful uprisings in Jordan, Morocco and Bahrain where success was defined as the overthrow of the previous regime. He concluded that the three important variables for the success or failure of these uprisings were the elite unity, the organizational diffusion, and the level of democratization achieved in the country prior to the uprising. He concluded that the uprisings in Tunisia and Egypt were successful as they got six and seven variables out of seven while the uprisings in Jordan, Morocco and Bahrain were unsuccessful because they got less than four variables. ${ }^{10}$

This study however, is framed on both the Theory of Social Movement and Theory of Political Islam as the later holds greater applicability to the Arab uprising, especially its political and religious dimensions. The role of political Islam was and still is, a central concern for many Arab and foreign academics and politicians. One of the main questions that have occupied political sociologists, politicians and political scientists, is whether Islam is a peaceful or evil religion and more importantly, whether or not Islam is compatible with democracy. Indeed, this subject gained increasing political, social and security significance among many Arab and Western scholars, and influenced the agenda of Islamic movements even before the Arab Spring. ${ }^{11}$ Analyses of this issue are generally marked, sometimes by prejudice and misunderstanding as for many Western analysts, political Islam is not compatible with democracy. They argued that political Islam is not only against democracy but also prevents many Islamic countries from moving towards modernization and democracy. ${ }^{12}$ Huntington claimed that the traditional conflict between the old ideologies was replaced by conflict between civilizations and he especially singled out Islam to be the major source of future conflict with Western civilization. ${ }^{13}$

The second view argues that political Islam is not against democratic principles; rather the ideologies of moderate political Islamists are compatible with the main principles of Western democracy, and that Islam calls for Shura, justice and 
respect for other religions. ${ }^{14}$ Some argued that it is too simplistic to say that Islam is against democracy or intolerant towards others and considered such views as far from the truth. ${ }^{15}$ Others argue that the Islamists' call for democracy is not genuine but they do so because they have discovered that political participation is the easiest way to gain political power. ${ }^{16}$ As for the relationship between political Islam and democracy, literature on the Arab Spring provides some thoughts about the main demands made during the uprising. Evidence shows that Islamic rule was not among the protesters' main demands. Indeed, the uprisings started without political leadership, religious motivation or left, right ideology, and for the first time, their protest and rallies were directed against their undemocratic governments and their failed socio-economic and political policies. The majority of protesters were not Islamists; rather they were youth, adults, men, women, Muslims, Christians, secular and religious people who came from all walks of life demanding freedom, dignity, and improvement of their living conditions but later they called for political reform and overthrow of autocratic rulers. As for the causes of the Arab Spring, there are many factors that played significant role in the uprising and its diffusion to other countries. Among them were inequalities, poverty, unemployment, unjust distribution of wealth, corruption and repression. ${ }^{17}$

Democracy and political reform were among the protesters' demands. However, these were not major factors that led to the uprising because Arab societies are still traditional and adhere to Islamic values while democratization requires major shifts in peoples' social values and modernization. ${ }^{18}$ Accordingly, if such theories will be used to explain the Arab Spring, one would expect that those who participated in the uprising were the youngest; the more educated; who most believe in democracy and less religious, more than the illiterate and elderly. ${ }^{19}$ Indeed, reports confirmed such views as it revealed that the majority of the people who participated in the uprising were largely young and educated. ${ }^{20}$ Literature on social movement also asserted the importance the role played by NGOs, political parties and other organized groups in providing coordination and organizational capabilities for large scale uprisings and revolts. ${ }^{21}$

Before the 2011 Arab Spring, the Middle East was frequently seen from Western perspectives as a uniquely undemocratic region with little activity by organized groups and civil society. However, the Arab Spring has challenged the Social Movement Theory's classical concepts of political opportunity, collective action and mobilization structures. Evidence on the Arab uprisings showed that NGOs, professional associations, civil society organizations, political parties and mosques in the Arab world not only exist but also played a significant role in the uprisings. ${ }^{22}$

\section{Arab Spring Dynamics and Impact on the Middle East}

The Arab Spring started in Tunisia on December 17, 2010 when Mohamed Bouazizi set himself on fire in protest against humiliation, despair and injustice at the hands of a local municipality official. This incident sparked a wave of protest across Tunisia and led to the overthrow of President Ben Ali. Similar demonstrations, rallies, and massive protests erupted in many Arab countries 
including Bahrain, Yemen, Jordan and Syria as never before, in terms of their massive numbers, demands and social composition. ${ }^{23}$ The Arab Spring was in fact, a spontaneous movement that came about as a result of the accumulation of many socio-economic and political problems during the last three decades. ${ }^{24}$ Protesters came out first in small numbers calling upon their governments to provide them with better socio-economic conditions, freedom, jobs, respect of their rights as citizens, and life with dignity, equality, human rights and democracy. ${ }^{25}$ They started without political leadership, religious motivation, or any left or right ideology. For the first time, their protests and rallies were directed against their own governments and not against external enemies such as the U.S. or Israel. ${ }^{26}$

In a few months, the Arab social uprising attracted mass protesters and two Presidents were overthrown: Zine el-Adin Ben Ali of Tunis on 14 January, 2011 and Hosni Mubarak of Egypt on 11 February, 2011. These dramatic developments were not expected or even thinkable in the Arab world which has been ruled by autocratic regimes for decades. Many observers expected that other Arab regimes would fall one after the other but such expectations did not materialize as only four regimes, out of twenty two, had fallen so far. There are different explanations for the success or failure of social movements such as the support of new political actors; elite unity; scale shift of a social movement; external support; organizational diffusion and level of democratization. ${ }^{27}$

Many Arab regimes have adopted new measures to manage and control the uprising including, partially meeting demonstrators' demands, replacing unpopular governments, or by issuing new laws, conducting or promising political and economic reforms. ${ }^{28}$ The response of the Jordanian regime and the GCC to the uprising was a combination of security and economic measures to calm their protesters. ${ }^{29}$ The Islamic groups that initially benefited from the Arab Spring were the Moderate Islamists such as the Muslim Brotherhood in Tunisia, Egypt and Morocco. ${ }^{30}$ In contrast, the Muslim Brotherhood in Jordan refused all efforts by the government and proposals to participate in the political process. Indeed, the Muslim Brotherhood boycotted the two parliamentary elections that took place in 2010 and 2013. This radical position put them on a collision course with the regime and sparked internal conflict among its leadership.

In the final analysis, the Arab Spring was not about Islam, Islamic rule or democratic rule. It was about improving people's socio-economic conditions, political reform, dignity, freedom and fighting corruption. In the two cases were Muslim Brotherhood gained power and formed governments in Egypt and Tunisia, none of them advocated Islamic rule; rather they followed the old system of government which was yet again rejected by the people in both countries. The other important feature of the Arab uprising is its broad solidarity among the different components of society; the massive scale of protesters and more importantly, that they became fearless of oppression. ${ }^{31}$

However, by the middle of 2013, the initial success of the uprisings and the rise of the Muslim Brotherhood to power came to an end. New radical Islamist groups emerged and dominated the political and military scene in the Middle 
East, and the rule of Muslim Brothers' was replaced by the military or old elites in Egypt and Tunisia. The other important impact of the Arab Spring is the emergence of many radical Islamic groups such as Daesh, ISIS, Jubhat alNusrah, Ahrar Al-Sham in Syria and Iraq; al-Hothies in Yemen, and many other groups in Egypt, Libya and the GCC countries. Moreover, many Arab countries suffer from chaos and civil wars that required the intervention of international and regional alliances to fight these radical groups in Syria, Iraq, Yemen and Libya. The violence and terrorism committed by some members of the Muslim Brotherhood and other radical Islamic groups in Egypt after the military coup supports the notion that exclusion may lead to radicalization while the behavior of the Islamists in Tunisia supports the notion that inclusion leads to moderation. The appearance of these radical groups affected the image of all Islamic groups and scared the people from Islamists' rule, especially after the beheading, torture and other atrocities committed by Daesh, the Islamic State and other radical Islamists groups.

\section{The Effects of Arab Spring on Islamists in the Middle East}

The Arab Spring has had different effects on Islamists in each Arab country. At the beginning, it had positive effects on the Muslim Brotherhood in Tunisia, Egypt and Morocco as the movements won majority seats in the parliamentary elections and formed governments in these three countries. It had less positive impact on Islamists in Jordan, GCC and other Arab countries. The other important impact of the Arab Spring was the emergence of several radical Islamic groups such as Daesh, ISIS, al-Nusrah in Syria and Iraq, the Islamic movement in Libya and Shies movement in Bahrain, al-Hothies and al-Qaeda in Yemen. The declaration of the Islamic Khilafah in large parts of Syria and Iraq, the chaos and civil wars in Syria, Iraq, Libya and Yemen, opened the door for more radical Islamist groups to appear throughout the Middle East. Indeed, many Arab countries today are facing direct or indirect challenge to their security and stability by some of these radical Islamist groups which continue to change their alliances, names and ideologies.

The worst impact of the Arab Spring was on the Muslim Brotherhood in Egypt as the movement was not only removed from political power but also banned and considered a terrorist organization in Egypt, Saudi Arabia, and the United Arab Emirates. The Islamic movement also lost political rule in Tunisia and majority in Turkey where they are still forming a major political group and allowed to participate in the general elections. The position of the Islamist movement in Morocco was slightly improved as they won majority in parliament, formed the government and enjoy the king's confidence.

In short, the Arab Spring has had disastrous impact on the so called moderate Islamists while it boosted the power and influence of the radical Islamists in the region. Today, many Arab countries face internal conflict, civil wars and terrorism which are expected to continue for years. Among the worst affected are Syria, Iraq, Libya and Yemen. The United States has formed international alliances to fight Daesh, ISIS and other radical groups in Syria and Iraq; Saudi Arabia formed regional alliance to fight al-Hothies in Yemen; and local 
authorities in Egypt, Libya, Bahrain, Jordan, Kuwait and Algeria are fighting radial Islamist groups in their countries and it is expected that the fight against these radical groups will continue for years to come.

\section{Arab Spring Inspiration to the Muslim Brotherhood in Jordan}

When the Arab Spring started in Jordan, several Muslim Brotherhood leaders made no secret of their view that the uprising has shifted the internal balance of political power to their advantage. Indeed, the empowerment of Muslim Brotherhood parties in Tunisia, Egypt, and Morocco and the sight of successive Arab regimes falling down one after the other under pressure from the uprisings boosted the morale of the Muslim Brotherhood in Jordan and raised their claim to achieving political power like their sister movements in Egypt and Tunisia. Ghaith al-Qudah declared that, "What's happening now in the Arab world is giving us a clear message that we can make changes and that all Arab regimes should understand this reality." 32 Another Brotherhood member declared, "We use the parliamentary elections results in other Arab countries to say to our government look, when the elections are fair, the Islamists will win." 33 "The Arab people are religious by nature and regardless of Westernization and Globalization when they are given a free choice they choose Islamists to rule." ${ }^{\prime 3}$ "The Arab Spring today uncovered the real power of the people, look at alNahda in Tunis, after years of exile, they came back and the people elected them." 35

Ruhayil Gharaibeh, despite knowing that the Arab Spring was originally initiated by non-Islamist youth, claimed that the Islamic movements were behind the Arab Spring. "The Arab Spring is one of the fruits of Islamic movement's activities and work. This is precisely what the Muslim Brotherhood has been working to achieve during the last eighty years." 36

The Muslim Brotherhood in Jordan followed similar actions and called for similar demands introduced by other Islamic movements but stopped short of calling for regime change. They organized regular demonstrations, rallies and public meetings in major cities. At the end of each event, they repeated their demands of amending major constitutional articles, especially those related to the king's power to dissolve parliament (Article 34); appoint the prime minister (Article 35), and appoint members of the Upper House (Article 36). The leaders of the Muslim Brotherhood argued that the Constitution should empower the people to be the source of authority (Articles 1, 24); that the political party which wins the majority should be entitled to appoint the prime minister; the Upper House should either be abolished or elected by the people and finally, there should be safeguards against arbitrary dissolution of parliament by the King. They repeated these demands in all media outlets and on TV screens, newspaper interviews and published it on their official web pages. ${ }^{37}$ It is worth mentioning here that these demands represented a bold departure from their traditional demand, that is modern election law, and indeed were inspired by the empowerment of the Muslim Brotherhood in Tunisia and Egypt. Indeed, questioning the King's power had been unthinkable before the Arab Spring even in moments of political crisis. ${ }^{38}$ 
Alongside this detailed statement, many leaders of the Muslim Brotherhood referred to the Moroccan experience as an example to the Jordanian regime to follow through, especially appointing the leader of the majority party as Prime Minister. ${ }^{39}$ Some of them considered the Moroccan model as the "least costly solution for solving the current crisis in Jordan and to reach a compromise between the desires of regime and the people." 40 Others even went further and suggested a ceremonial role for the king "as we can't continue living under a form of rule that goes back to the Middle Ages, whereby one person exercises all the power without accountability." $41 \mathrm{He}$ continued to say, "I believe all Arab regimes will change and the only difference between countries will be time and the scale of change; that all corrupt oppressive regimes will be removed; that there will be a democratic system based on freedom and political participation and that Jordan will definitely be part of this process." 42

Nimr al-Assaf, expressed a similar view when he said: "We are in the 21 st century, and nobody accepts absolute power to be in the hands of one single person; no way." ${ }^{43}$ However, the JMB leadership understood the consequences of crossing the red lines regarding the King's status and power; therefore they stopped short of calling for regime change as the case in other countries. Indeed, no senior leader of the IAF or the JMB has called for changing the Hashemite rule. To the contrary, most of those leaders affirmed the importance of the monarchy to Jordan's stability and national unity.

However, there was no agreement among all members of the Muslim Brotherhood leaders about these radical demands and statements and more importantly, their decision of boycotting the parliamentary elections in 2010 and 2013. Indeed, some of the Jordanian members of the leadership announced publically their disagreement with these statements and positions. They were afraid that any major constitutional changes would give the Jordanians of Palestinian origin greater role in the political future of the country at the expense of the Jordanian people. These internal differences among the JMB leaders had led first to the establishment of Zamzam Movement and later, to the establishment of the Society of the Muslim Brotherhood in Jordan which was immediately licensed and recognized by the Jordanian government.

\section{The Role of the Muslim Brotherhood in the Uprising in Jordan}

The uprising in Jordan was initiated by a group of youth in Dhiban, a small village near Amman, in 2010 and spread to other parts of the country. On $7^{\text {th }}$ November, 2011, the IAF and the JMB quickly joined the uprising (Hirak) with other opposition political parties and groups. ${ }^{44}$ The JMB did not participate in the initial phase of the uprising in Jordan which was dominated largely by several groups of youth protesters, but once they realized the success of the uprising in neighboring Arab countries, they not only started to participate in the uprising but also took over the leadership of the movement, which became known locally as "the mobilization" or (al-Herrak). Indeed, the IAF and JMB began to organize and mobilize regular demonstrations and rallies in Amman and other major cities on a larger scale more than ever before. As the Arab uprisings have expanded across the region, the JMB increased their mobilization activities and conducted 
substantial popular demonstrations in Amman, Irbed, and Zarqa, demanding the regime to make far reaching socio-political reforms and fixing the whole political system. $^{45}$

There is no dispute that the JMB is the main opposition group in Jordan with political experience, organizational skills, financial resources and popular support. It is true that there are the so called national movement, leftists and other Islamic political parties but they could not compete with the Islamic movement. The JMB has vast numbers of members and supporters in addition to a long history of providing social, educational, and medical services and organizing public events that enabled them to control the street. ${ }^{46}$ One member of the movement claimed that 90 percent of demonstrators were from the Islamic movement and without them there would not be many demonstrators. ${ }^{47}$ However, the JMB in a move to show their leadership of the national uprising, coordinated and cooperated with other established opposition political parties and the newly fragmented regional Hirak committees. Thus, the main logic behind JMB strategy to cooperate with other political parties and groups was not only to increase overall pressure on the regime, but also to show the regime and the public that they are the main political opposition in the country.

The JMB used the mosques as meeting places because they knew that the government would not dare to prevent people from going to pray. Indeed, they took advantage of the Friday prayer to organize regular rallies and demonstrations. At the end of each rally, they arranged for some of their leaders and other prominent opposition leaders to give speeches about their demands which were transmitted live by TV stations, and other social and mass media outlets. The main weekly event was a regular rally, led by JMB leaders marching arm-in-arm with other opposition leaders from al-Hosseini Mosque to al-Nakheel Square in downtown Amman. Their demands were usually a reflection of the IAF and JMB written statement which included the following: real political reform; changing the election law; amending the constitution; empowering the people to be the real source of power; limiting the Kings authority to dissolve parliament; rejecting government's superficial, illusory and cosmetic reforms. ${ }^{48}$

However, despite the fact that most demonstrations were concluded peacefully, a youth activist group seized the Jamal Abdel-Nassir roundabout in Amman, on March 24, 2011, and declared an open sit-in. Although this move was not officially led by the JMB leaders, but most of the protesters were Muslim Brotherhood and IAF members. ${ }^{49}$ This sit-down was the first Jordanian emulation to the sit-down events in Tahrir Square in Egypt. However, the following evening, security forces and a large group of pro-regime activists cleared the bridge area from protesters, leaving one protestor dead and many others wounded from both sides. ${ }^{50}$ In December 2011, police dispersed another sit-down attempt in front of the Prime Minister's Office on the $4^{\text {th }}$ Square that was organized by IAF and JMB members. The security forces dispersed yet another Brotherhood rally in Mafraq, during which local pro-government activists burned the headquarters of both JMB and IAF. ${ }^{51}$ 
However, it was speculated whether or not such attacks were executed by progovernment activists or indeed coordinated or encouraged by the security forces. The head of the IAF Youth Sector accused the intelligence department of being behind them, "We have two governments one formed by the King and other is the intelligence department. The regime wants to control the Muslim Brotherhood but that is not going to happen." 52 Another JMB member expressed the movement's resolve to continue its political activities in their demands. ${ }^{53}$ The Muslim Brotherhood leadership thought that time was on their side and therefore, they rejected all government efforts and proposals for political reform and continued their weekly rallies in the hope of getting a better deal. "Now, our movement is irreversible and I pray for God to help our king to take the right and brave decision to avoid Jordan the fate of Syria and Yemen." 54 By taking such radical position, they placed themselves on a collision course with the regime.

\section{Regime Responses to the Arab Spring in Jordan}

In January 2011, Jordan, like other Arab world countries, was hit by continuous waves of protests, rallies and demonstrations demanding socio-economic and political reform. The demonstrators consisted of men and women of all ages, but mainly youth from different backgrounds including nationalists, Islamists, leftists, unemployed and educated people without specific religious or political orientations. Protesters called upon the government to take serious measures to solve poverty, unemployment, the rise of taxes, prices hikes and rampant corruption. Other demands included dismissing the government, dissolving parliament, amending the electoral law, and conducting fair and free elections. ${ }^{55}$ The King responded positively to some of the protesters' demands by dismissing five governments in two years and took several other steps including the establishment of an Independent Commission to oversee elections; a Constitutional Court to monitor legislation, and other independent bodies to oversee the elections and to fight corruption, amended the election law to include 27 seats for the nationalists and continued its up-dawn political and economic reform policies. However, he stopped short of limiting any of his executive powers. ${ }^{56}$

Despite positive responses from the general public and the national media for these steps, Hamam Sa'id, Brotherhood General Supervisor, declared that these measures and proposals "did not make the people the source of political power." ${ }^{57} \mathrm{JMB}$ and Islamic Action Front issued a joint statement rejecting these proposals asserting that: "The government wasted an opportunity to conduct substantial amendments to the structure of the political system; to render to the people their rights as the source of powers; to respond to peoples' demands for real reform and to meet the challenges that are facing the country." 58

The response of the Jordanian regime to the Arab Spring was different from other Arab countries in general and Egypt in particular, especially in terms of dealing with the Muslim Brotherhood in so far as the Jordanian government did not ban the movement. Instead, it encouraged internal conflict, the establishment of other Islamic political parties like al-Wasat party, gave license to new society for Muslim Brotherhood, and deals with JMB as a non-licensed organization with 
the possibility of allowing the new society to take over all its assists, property, and institutions with the possibility of banning the movement unless it gets a license. It can be said that Jordan has passed the wave of the Arab Spring peacefully but is still facing serious challenges from radical Islamic groups in the neighboring Arab countries. It still has to decide what to do with the Muslim Brotherhood.

\section{The Failure of the Uprising in Jordan}

Many scholars have attempted to answer the question as to why the uprisings in Egypt and Tunisia were successful while it was not the case in Jordan and other Arab countries. They used different approaches to find answer to this question such as the Marxist Theory, the Social Movement Theory and Political Islam Theory. Sean Lynch used the Social Movement Theory to compare between the outcome of the Arab Spring in five Arab countries, Tunisia, Egypt, Morocco, Jordan and Bahrain. For him, a successful uprising is defined as one that overthrows the existing regime. The study concluded that the unity of the elite with the regime in power, the existence of mobilizing organizations in the country, and the level of democratization in each country before the uprising were the most important factors in the success or failure of the uprising. However, this study sought to determine the difference between the outcome of uprisings in Jordan and Egypt by using both the Social Movement and Political Islam theories to test the effects of eight variables (Table 1). These are: elite unity and support for the regime; the size and scale of the protest; the use of force; occupation of public places by the uprising; regime responses to protesters' demands; army intervention; population unity and support for the uprising, and finally the unity of the uprising. By examining the impact of eight variables on the different outcomes of the uprisings in Jordan and Egypt, the study revealed the following:

- In terms of the first variable, i.e., elite unity and support for the regime, it continued in Jordan during the last four years without any significant tribes, economic or political elites breaking away from the regime while the elite broke with regime in Egypt.

- Regarding the second variable, i.e., the scale and the size of the uprising and protests, the regime in Jordan not only succeeded in preventing massive protest and demonstrations but also confined them to certain areas; and allowed them to protest for a short time and in small numbers while protest and demonstration in Egypt were massive and the regime failed to control them.

- Regarding the third variable, i.e., the use of force against protesters, the regime in Jordan followed soft power to deal with protesters without any death or serious casualties among protesters. It is true that the government adopted a soft power policy to deal with the uprising and gave some space to demonstrators to express their views and demands, but at the same time, it established certain red lines, specifically against direct criticism of the king, and demonstrations inside the Palestinian refugee camps and tribal areas, on the ground that such activities would endanger the stability and national 
unity. The regime in Egypt however, used excessive force to disburse protesters which led to thousands of deaths and casualties among demonstrators and the police. The use of force in fact, upset more people and drove them to join the uprising.

- Regarding the fourth variable, i.e., occupation of public places and squares, the regime succeeded in preventing the protesters to occupy or sit-in in public places or major streets for more than a few hours to one day maximum. This action deprived the uprising from attracting massive protesters and media attention. The government allowed protesters to march after the Friday prayers through specific streets and for a limited time without disrupting the traffic or commercial activities. The uprising in Egypt, on the other hand, succeeded in occupying many public places in several major cities like the famous Tahrir Square. This gave the uprising a golden opportunity to attract thousands of people to join protests and take advantage of local and international media to advance their cause and document the regime's actions, especially the use of force.

- Regarding the fifth variable, i.e., the regime responses to demands made by the uprising, the reaction of King Abdullah II was quick, as on February1, 2011, he dismissed the government. Within one year of the uprising, he dismissed four governments on the ground that they failed to implement his vision of political and economic reforms. Moreover, the government established several independent bodies to fight corruption and monitor parliamentary elections; amended the election law and 41 articles of the Constitution; established a constitutional court and conducted two successful parliamentary elections in 2010 and 2013 without the participation of the Muslim Brotherhood. These reforms played a major role in satisfying part of the protesters' demands and in calming the majority of the people, and the Herrak almost came to complete halt. The regime in Egypt, on the other hand, rejected all protesters' demands and continued the use of force policy to quell the uprising.

- Regarding the sixth variable, i.e., the army intervention, the regime in Jordan did not use the army to deal and control the uprising as there was no such need for army intervention. The regime used a combination of security forces and the police to deal with the uprising and succeeded to bring it under control. There is no doubt that the Jordanian army is very loyal to the King and would not hesitate to support the regime if it was called for intervention. The regime in Egypt, on the other hand, called on the army to intervene after the failure of the security forces and the police to control the uprising. The regime was surprised when the army refused to intervene but also announced its support for the people. This was a severe blow to the regime and was one of the most important factors that led to the resignation of President Mobarak.

- Regarding the seventh variable, i.e., population unity and support for the uprising, the people in Jordan were not united in supporting the uprising as they are traditionally divided into Jordanians and Jordanians of Palestinian 
origin; north and south; Bedouin and city dwellers, etc. The government succeeded in playing these different groups against each other and created mistrust between them. In comparison, despite the regime's efforts in Egypt to use its supporters against the protesters, the majority of the Egyptian people preserved their unity and continued their support for the uprising.

- Regarding the eighth variable, i.e., the unity of the uprising, the regime succeeded in dividing the uprising into different rival groups on racial and religious lines: Jordanians - Palestinians; Islamists - liberals; tribal and refugees. In other words, the uprising was divided into small isolated groups without leadership, real cooperation or coordination, and more importantly, different agendas. While the Islamists concentrated on political change, other Herrak and opposition groups were more concerned with improving the socio-economic factors and living conditions. ${ }^{59}$ In contrast, the uprising in Egypt was united and there was coordination and cooperation between protesters in different cities; they carried similar banners, raised the same slogans, called for similar demands and had similar agendas. In the final analysis, the uprising in Jordan was practically divided between the Muslim Brotherhood which operated mainly in the major cities under Palestinian leadership and the Herrak which mainly operated in small towns and villages under multiple Jordanian leaderships. Moreover, it failed to mobilize new actors, or to unite its leadership or agenda, and consequently, continued to work in small separate groups with different agendas and demands, without united leadership, and failed to use social media effectively to organize activities, demonstrations and rallies. ${ }^{60}$

It seems that the important factors in determining the success or failure of the Arab uprising in Jordan and Egypt are: elite unity and support for the regime; the army intervention, people unity behind the uprising and the unity of the uprising; the scale and massiveness of the uprising and protest; the ability of the uprising to occupy public squares and places.

Egypt scored five out of eight variables while Jordan scored only two out of eight variables. This means that the uprising in Egypt was successful in overthrowing the regime because it enjoyed the support of the people; the elite broke unity with the regime, it was a massive movement, succeeded in occupying many squares and public places, the army refused to support the regime, the regime did not respond positively to protesters' demands, and used excessive force against protesters which caused many deaths and casualties among the population. The uprising in Jordan was not successful because of the continuation of elite unity with the regime; small scale protest; the regime used soft power instead of force; did not allow protesters to occupy public places; responded positively to protesters' demands; there was no public unity behind the uprising and finally, the uprising was not united; rather it was fragmented. 
Table 1: Uprising and Regimes Variables

\begin{tabular}{|l|l|l|l|}
\hline & Variables & Egypt & Jordan \\
\hline 1 & $\begin{array}{l}\text { Elite unity and support for the } \\
\text { regime }\end{array}$ & United & Divided \\
\hline 2 & Size and scale of protest & Massive protest & $\begin{array}{l}\text { Limited and } \\
\text { fragmented protest }\end{array}$ \\
\hline 3 & $\begin{array}{l}\text { The use of force against } \\
\text { protesters }\end{array}$ & Excessive force & Soft power \\
\hline 4 & Occupation of public places & On large scale & Not allowed \\
\hline 5 & $\begin{array}{l}\text { Regime responses to uprising } \\
\text { demands }\end{array}$ & No & Yes \\
\hline 6 & Army intervention & Refused to intervene & $\begin{array}{l}\text { Not tested/ ready to } \\
\text { intervene }\end{array}$ \\
\hline 7 & $\begin{array}{l}\text { Population unity and support for } \\
\text { the uprising }\end{array}$ & United society & Divided society \\
\hline 8 & The unity of the uprising & $\begin{array}{l}\text { Regime change/ } \\
\text { overthrow }\end{array}$ & No regime change \\
\hline
\end{tabular}

\section{The Impact of the Arab Spring on the Political Future of the Muslim Brotherhood in Jordan}

The uprising in Jordan however, was started by small youth groups in different parts of the countryside. In November 2011, it developed into a popular movement which spread into the major cities and Friday protests became regular in Jordan for the last three years. The uprising in Jordan was divided into three groups: the Islamists who were mainly from the Muslim Brotherhood and the IAF; al-Herrak which consisted of independent youth, nationalists, leftist groups and political parties. At the beginning, the Muslim Brotherhood hesitated and was reluctant to join the uprising but during the last three years, it practically dominated and led the uprising's activities in the major cities. It coordinated some of its activities with the nationalist and leftists groups, especially after Friday prayers. The Muslim Brotherhood and the nationalist groups were more interested in political change and therefore, they called for fixing the political system and limiting the King's powers. Al-Herrak, on the other hand, worked in smaller numbers and isolated groups across smaller towns and villages. They were more interested in improving the socio-economic conditions; solving poverty, unemployment, fighting corruption and improving the living conditions of the people. The JMB leaders, inspired by the success of other Islamists, felt they were in a strong position. They refused to participate in the political process unless the regime met all their demands and therefore, rejected all government proposals for political and economic reforms, and boycotted the 2010 and 2013 general elections.

However, things have changed dramatically during 2014-2015. The Muslim Brotherhood in Egypt and Tunisia has lost political power and more importantly, the Muslim Brotherhood in Egypt was banned and considered terrorist organization in Egypt, Saudi Arabia and United Arab Emirates. Moreover, several new extreme Islamists groups have emerged such as Daesh, ISIS and al- 
Nusrah in Syria, Iraq and Libya; and al-Hothies in Yemen. This has caused chaos and civil wars in Syria, Iraq, Yemen, Libya and other Arab countries. The ISIS or Daesh rule in Syria and Iraq, Muslim Brotherhood rule in Egypt and Tunisia, and al-Hothies rule in Yemen have changed people's minds and attitudes toward Islamists in the Arab world. Indeed, the violent nature of the Islamic state rule, especially the beheading of people's burning the Jordanian pilot, and their terrorist attacks in Kuwait, Saudi Arabia, Tunisia, Algeria, Morocco and Egypt have changed people minds towards Islamists in the region; they have even lost majority rule in Turkey and Tunisia. By insisting on their radical demands and boycotting the parliamentary elections in 2010 and 2013, the Muslim Brotherhood has alienated itself from the public and set the scene for confrontation with the regime.

Moreover, the appearance of many radical Islamist groups, the civil wars in neighboring countries and the refusal to participate in the parliamentary elections has weakened their position in the public eyes. This has created serious internal conflict among its leadership. The first sign of this internal conflict was the establishment of Zamzam Movement which was followed by the establishment of the "Society Muslim Brotherhood in Jordan." This move of the government has practically split the Muslim Brotherhood into two rival groups; one dominated by Palestinian extreme leadership and the second led by moderate Jordanian leadership. This is in addition to the existence of other Islamic Salafist, Jihadist groups, and other political parties such as the Wasat Party which has participated in the political process since 1993 and won 15 seats in the 2013 elections.

Today, the government does not recognize the old Muslim Brotherhood as a legal organization. It refused to grant the movement permission to organize a public gathering to celebrate the $70^{\text {th }}$ anniversary of the Islamic movement on the ground that it is not a legal organization. Consequently, the movement cancelled that event which is a clear sign of its weakness. However, the government position on the movement is still vague as it did not announce a clear position as what to do with JMB if it does not get a license. But it is unlikely that it will ban the JMB in the near future because such an action might have serious security and political implications. Therefore, it is expected that the status quo will continue as long as it serves the interests of the regime. Indeed, the Muslim Brotherhood movement in Jordan today is far weaker than before and the government has succeeded in weakening the uprising by playing protesters from the Islamists, the political parties and al-Herrak against each other in a way that led to the disappearance of the uprising dangers to the regime and the country. It is safe to say that the Muslim Brotherhood is still a major opposition party in Jordan but surely it has lost its workable relationship with the regime.

\section{Conclusion and Recommendations}

The Arab Spring has developed new realities upon which political sociologists and scholars of social movements could use a variety of sociological theories to explain these uprisings. This paper uses a combination of Social Movement and Political Islam Theories as a framework to explain the dynamics of the Arab 
Spring and its impact on the political future of the Muslim Brotherhood in Jordan and the Middle East.

The Arab Spring was a spontaneous social movement which started in Tunisia and spread all over the Arab world. The majority of the protesters were young people who came from all walks of life without any specific religious or political ideologies and they did not call for Arab unity, Arab nationalism or Islamic rule. They were later joined by Islamists and members of other leftist and opposition political parties and groups. Their main demands were focused on improving socio-economic conditions; employment opportunities; fighting corruption; freedom and respect of dignity and human rights. The uprisings in Egypt and Tunisia started peacefully but they were met with brutal responses from both regimes. The death and injuries of thousands of protesters in both countries has changed the dynamics of the uprisings, and attracted million of protesters who marched through many major streets and occupied public places. The excessive force used by the regimes has changed protesters' demands from socio-economic reform to overthrowing the regimes; within two months of continued massive pressure both presidents were forced to resign.

The Muslim Brotherhood in both countries took advantage of the situation, joined the uprising, participated in the parliamentary elections and formed governments in both countries. Indeed, it emerged as the real winner in both countries while youth organizations and other groups who initiated the uprisings got nothing.

The rise of the Muslim Brothers to political power in Egypt has inspired many Muslim Brothers and other Islamist groups and parties in Jordan and other Arab countries. It motivated them to join the uprisings in their countries. However, in 2013 and 2014, the Muslim Brotherhood in Egypt and Tunisia not only lost political power but was declared a terrorist organization in Egypt. It was also banned in Egypt, Saudi Arabia and UAE.

Therefore, the main conclusion of this paper is that the Arab Spring has had disastrous impact on the political future of the so called moderate Islamists, namely the Muslim Brotherhood in the Arab world in general, and Egypt and Jordan in particular. The second important result of the Arab Spring is that it opened the door for the appearance of many new radical and extreme Islamic groups such as Daesh, ISIS, al-Nusrah in Syria and Iraq, the Hothies and other groups in Yemen, Libya and Sinai in Egypt, and spread radicalism and terrorism throughout the region.

The third conclusion is that international and regional intervention is supporting the uprising. The United States and many other European countries intervened in Libya, Syria and Iraq while Saudi Arabia and other Arab countries intervened in Bahrain and Yemen. The international intervention in the above countries resulted in continuous chaos and civil wars.

The Arab Spring has deeply changed the socio-political structure and created internal conflict in several Arab countries including Tunisia, Libya, Syria, Iraq, and Yemen, with fewer effects on Jordan, Morocco and the GCC countries. The 
first four Arab regimes were removed from power in Egypt, Tunisia, Libya and Yemen and few others suffer from civil wars, chaos and terrorism in Syria, Iraq, Egypt and Yemen. The appearance of Daesh, ISIS and other radical groups and their brutal crimes against civilians contributed to the negative image of the Islamists in general and frightened people from any form of Islamic rule.

The Muslim Brotherhood Movement in Jordan was inspired by the success of its sister movements in Egypt and Tunisia. They expected real political concessions from the regime, and more diplomatic and financial support from the Muslim Brotherhood in Egypt. Muslim Brothers' victories in neighboring Arab countries led them to believe that they might get more support from the Jordanian public, but they were wrong as none of these expectations have materialized. Moreover, in a miscalculated move, they rejected all government's efforts and proposals to participate in the political process on the ground that the suggested proposals did not meet the minimum requirements for real democracy. Consequently, they boycotted the 2010 and 2013 parliamentary elections. They continued their protest activities and co-sponsored thousands of demonstrations and rallies across the country, especially after Friday prayers in Amman and other major cities. However, they did not call for the regime to be overthrown, and they did not challenge the legitimacy of the Hashemites. The government made some concessions but the Brotherhood rejected these concessions and tensions between them and the regime exacerbated, especially after they refused to participate in parliamentary elections.

The uprising in Jordan however, has failed because the government responded positively but partially to protesters' demands. The government succeeded in dividing the uprising by playing them against each other, preventing them from sit-ins in public places or streets, and used soft power to control and manage the protest. The government followed the old "divide and rule" policy as it encouraged internal conflict and practically split the movement into two rival groups; succeeded in dividing the uprising into several groups such as Jordanians-Palestinians; Islamists versus non-Islamists, and different Herrak such as North Herrak versus South, and cities versus countryside. This strategy practically brought the uprising to a complete halt.

Moreover, the July 2013 military coup in Egypt turned the tide against the Muslim Brotherhood Movements in the region and had profound effects on the Jordanian Brotherhood. The majority of the Jordanians became less interested in the uprising, especially after the Muslim Brotherhood was banned and declared a terrorist organization in Egypt, Saudi Arabia and the United Arab Emirates; the spread of chaos and civil wars in neighboring Arab countries; and the arrival of more than 600,000 Syrian refugees in Jordan.

Moreover, the appearance of many radical Islamists group, the civil wars in neighboring countries and JMB's rejection to participate in the parliamentary elections has weakened their position in public eyes and created serious internal conflict among its leadership. The first sign of this internal conflict was the establishment of Zamzam Movement which was followed by the establishment of the Society Muslim Brotherhood in Jordan which was immediately granted 
licenses by the government. As mentioned earlier, this government move has practically split the Muslim Brotherhood into two rival groups, one dominated by Palestinian extreme leadership and the second led by moderate Jordanian leadership. However, it is too early to say what the impact of such a split would be on the political future of the JMB. One should remember that the Movement has survived similar breaking away before, such as the Islamic Center Party ten years ago and the defection and resignations of many of its prominent leaders. However, the Muslim Brotherhood is still a major political force in Jordan. It has lost some of its popularity and entered a wait and see phase of its legal existence. This split is the only problem facing the JMB. There are other rival political Islamic groups such the Salafists, the Jihadists and other political parties such as the Wasat Party which participated in the political process since 1993 and won 15 seats in the 2013 elections.

The other factor that contributed to the decline of the JMB's influence is the government decision to prevent their members from leading prayers or preaching in mosques. The double shock of the fall of President Morsi in Egypt and the rise of ISIS in neighboring Iraq and Syria have fundamentally changed the relationship between the regime and JMB, and altered the regime's strategy towards dealing with the movement. It is safe to say that having survived the initial wave of the Jordan Spring, the regime became confident that it can maintain stability without making major compromises on political or institutional reforms.

Regarding the political future of the Muslim Brotherhood in Jordan, it seems that the government position and policy towards its political future and legal existence is still vague. In September 2015, the government introduced a new election law in parliament that abrogated the one man one vote system and adopted a multi-vote system. The new law was received positively by many political circles and the press but it is not clear what the position of the old JMB would be regarding the coming parliamentary elections. However, it is unlikely that the government will ban the JMB before the coming election and such decision must wait until after the election. 


\section{Recommendations}

\section{a. For the Government}

- Continue the process of political reform in a more meaningful way toward a real democratic governance

- Solve poverty, unemployment and other socio-economic problems

- Allow more freedom of speech, press, mass and social media

- Check and monitor the contents of teaching materials, practices, and regulations of all private and government religious schools and institutions, and employ qualified people to run them

- Fight all types of financial, administrative corruption and all types of Wastah, connections and bribery in more aggressive way

- Invest more in socio-economic development programs, education and health care systems, especially in the northern and southern poor areas

- Counter Islamist and jihadist radical ideas through state media and education programs at schools and universities.

- Control and limit the influx of immigration to the country and work with other international organizations to facilitate their safe return to their countries

\section{b. For the Islamic Movement in Jordan}

- Get a new license as a Jordanian independent organization and not as a branch of the Egyptian Movement because the law does not allow such affiliation with outside organizations

- Decide whether it wants to be a religious and da'wa movement and concentrate its efforts on its traditional socio-economic, educational medical and other charitable services; or transform itself into a political party. 


\section{References and Endnotes}

1 Sidney Tarrow,. and Charles Tilly, "Contentious Politics and Social Movements," Oxford Handbook of Comparative Politics. July 2009. DOI:

10.1093/oxfordhb/9780199566020.003.0019

2 John. D. McCarthy, \& Zald, N. Mayer. Resource Mobilization and Social Movements: A Partial Theory," American Journal of Sociology, 82, (1977): 121241; John Wilson, Introduction to Social Movements. First Edition. (New York: Basic Books, 1973); Charles Tilly, and Lesley Wood, Social Movements 1768-2012. Third Edition. (Boulder, Co: Paradigm Publishers. 2012); Anthony Oberschall, Social Conflict and Social Movements (Englewood Cliffs, N.J.: Prentice-Hall. 1973); J. Craig Jenkins, "Resource Mobilization Theory and the Study of Social Movements," Annual Reviews Inc. Ann. Rev. Social. (1983) 9:527-53; William A. Gamson, The Strategy of Social Protest. Second Edition. (Belmont, CA: Wadsworth Publishing, 1990).

3 Charles Tilly, From Mobilization to Revolution (Reading, MA: Addison-Wesley, 1978).

4 McAdam, Doug. McCarthy, John D and Mayer. N. Zald, Comparative Perspectives on Social Movements: Political Opportunities, Mobilizing Structures, and Cultural Framing (New York: Cambridge University Press, 1996)

5 Gamson, The Strategy of Social Protest, Op. cit; Charles Tilly, Contentious Performances (New York: Cambridge University Press. 2008); Doug McAdam, Sidney Tarrow and Charles Tilly, Dynamics of Contention (New York: Cambridge University Press, 2001); Bevington Douglass. \& Dixon Chris, "Movement-relevant Theory: Rethinking Social Movement Scholarship and Activism," Social Movement Studies: Journal of Social, Cultural and Political Protest. 4(3):185-208.

$6 \quad$ Fawaz Gerges, Contentious Politics in the Middle East: Popular Resistance and Marginalized Activism beyond the Arab Uprisings (London: Palgrave Macmillan, 2015).

7 JonathanChristiansen, "Four Stages of Social Movements,".EBSCO Publishing Inc. 2009. https://www.ebscohost.com/uploads/imported/thisTopic-dbTopic-1248.pdf

8 Karl Marx, and Frederick Engels, Selected Works in One Volume (New York: International Publishers, 1968), 35.

9 Sean Lynch, "The Arab Spring: Understanding the Success of Protest through Social Movement," Washington Research Library Consortium, 2013. http://aladinrc.wrlc.org/bitstream/handle/1961/15059/Lynch,\%20Sean\%20$\% 20$ Spring\%202013.pdf? sequence $=1$

10 Ibid.

11 Ahmad Moussalli, The Dialectics of Shura and Democracy: Democracy and Human Rights in the Islamic Thought (Beirut: Center of Arab Unit Studies (Arabic), 2007; Augustus Norton, Civil Society in the Middle East (New York: Brill. 1995); John L. Esposito, "Islam and Secularism in the $20^{\text {th }}$ First Century," in Islam and Secularism in the Middle East, Ed. John L. Esposito and Azzam Tamimi, (New York University Press, 2000); Abdelmahdi Alsoudi, "The Impact of US Aid Policy on Democracy and Political Reform in the Arab World," International Journal of the Humanities, 4(10) (2007): 113-126; Fawad Gerges, Contentious Politics in the Middle East: Popular Resistance and Marginalized Activism beyond the Arab Uprisings, 2015; Khaled Hroub, Ed. Political Islam: Context versus Ideology (SOAS Middle East Issues). (London: SAQI, 2010); Nazih Ayubi, Political Islam: Religion and politics 
in the Arab World (London: Rutledge, 1991); Salwa Ismail, Rethinking Islamist

Politics: Culture, the State and Islamism (New York: IB Tauris and Co. Ltd., 2006.

12 Bernard Lewis, "Islam and Liberal Democracy: A Historical Overview," Journal of

Democracy. 7 no., 2, (1996), 52-63; Samuel. P. Huntington, The Clash of

Civilization and the Remaking of the New World Order (Touchstone, New York:

Simon and Schuster, 1996); Francis Fukuyama, The End of History and the Last Man

(New York: The Free Press, Macmillan Inc., 1992).

13 Samuel P. Huntington, The Third Wave: Democratization in the Late Twentieth Century (USA: University of Oklahoma Press, 1993).

14 John L. Esposito, "Islam and Secularism in the 20 $0^{\text {th }}$ First Century," in Islam and Secularism in the Middle East, eds., John. L. Esposito and Azzam Tamimi, (New York University Press, 2000); Dale. F. Eickelman, and James Piscatori, Muslim Politics (Princeton Studies in Muslim Politics), (Princeton, New Jersey: Princeton University Press, 2004); John L. Esposito, \& John O. Voll, Islam and Democracy (New York: Oxford University Press, 1996); Alsoudi, “The Impact of US Aid Policy on Democracy and Political Reform in the Arab World," 2007. Op. cit. 8; Seif Da'na, "Islamic Resistance in Palestine: Hamas, the Gaza War and the Future of Political Islam," Holy Land Studies, 8.2(2009): 211-228.

15 Francois Burgat, Face to Face with Political Islam (New York: IB Tauris and Co. Ltd, 2003); Kamranand Bokhari, Farid Senzai, Political Islam in the Age of Democratization (London: Palgrave Macmillan, 2013).

16 Larbi Sadiki, Rethinking Arab Democratization: Elections Without Democracy (New York: Oxford University Press, 2009).

17 Stephan Haggard, and Robert Kaufman, "Inequality and Regime Change: Democratic Transitions and the Stability of Democratic Rule," American Political Science Review 106, no., 03, (2012): 495-516.

18 G. A. Almond, and S. Verba, The Civic Culture; Political Attitudes and Democracy in Five Nations (Princeton, New Jersey: Princeton University Press,1963); Larry Diamond, Juan J. Linz and Seymour Martin Lipset, (Eds.), Democracy in Developing Countries, Vol. 4, (Boulder, CO: Lynne Rienner, 1989); Huntington, The Third Wave: Democratization in the Late Twentieth Century, Op. cit. 9; Robert. A. Dahl, Polyarchy; Participation and Opposition (New Haven: Yale University Press, 1972); Ronald Inglehart, And Pippa Norris, Rising Tide: Gender Equality and Cultural Change Around the World (Cambridge, UK; New York: Cambridge University Press. 2003)

19 Seymour Martin Lipset, Political Man: The Social Bases of Politics (New York: Doubleday Anchor, 1963); Ronald Inglehart, "Values, Ideology, and Cognitive Mobilization in New Social Movements," In Challenging the Political Order: New Social and Political Movements in Western Democracies, eds. R. J. Dalton \& M. Keuchler, (New York: Oxford University Press, 1990), 43-66.

20 "The Arab Development Challenges Report 2011," United Nation Development Program (UNDP), 2012, http://www.undp.org/content/dam/undp/library/corporate/HDR/UNDP-ADCR_En2012.pdf

21 Doug McAdam, John. D. McCarthy, and Mayer. N. Zald, Comparative Perspectives on Social Movements: Political Opportunities, Mobilizing Structures, and Cultural Framing (New York: Cambridge University Press, 1996); Mancur Olson, The Logic of Collective Action; Public Goods and the Theory of Groups (Cambridge, Mass: Harvard University Press. 1971) 
22 Joel Beinin, and Frederic Vairel, Social Movements, Mobilization, and Contestation in the Middle East and North Africa (Stanford Studies in Middle Eastern and Islamic Societies and Cultures), Second Edition, (California: Stanford University Press, 2013)

23 Mehran Kamrava, "The Arab Spring and the Saudi-Lead Counterrevolution," Orbis 56.1 (2012): 96-104; Jillian Schwedler, "The Politics of Protest in Jordan," Foreign Policy Research Institute. February 2012. http://www.fpri.org/articles/2012/03/politics-protest-jordan; T.Schiller, "Tunisia-A Revolution and Its Consequences," KAS International Reports, 5: 6-19;Kamal Sedra, "The Role of Social Media and Networking in Post-conflict Settings: Lessons Learned from Egypt". 2013, The World Bank/TDRP, June 5-6 2013.

http://www.tdrp.net/PDFs/Social\%20Media\%20\&\%20Arab\%20Spring\%20\%20Egypt.pdf; Gause III, F. Gregory, Saudi Arabia in the New Middle East. Washington D.C.: Council on Foreign Relations. Council Special Report No. 63.2011.

24 Philip N. Howard, and Muzammil M. Hussain, "The Role of Digital Media," Journal of Democracy. 22, no. 3, (2011): 35- 48.

25 Aissa El Hassane, "The Arab Spring: Causes, Consequences, and Implications," Strategy Research Project. U.S. Army War College. 2012. www.dtic.mil/cgibin/GetTRDoc?AD=ADA560779.

26 Stephan Rosiny, "The Arab Spring: Triggers, Dynamics and Prospects," German Institute of Global and Area Studies, GIGA Focus. No. $1 / 2012$.

27 Lynch, "The Arab Spring: Understanding the Success of Protest through Social Movement," 2013. Op. cit. 7.

28 Paul Silverstein, "Weighing Morocco's New Constitution," Middle East Research

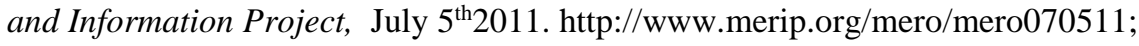
McCurdy Patrick, "Social Movements, Protest and Mainstream Media," SociologyCompass.6, no., 3, (2012): 244-255.

29 Danya Greenfield, "Jordan King Launches 'White Revolution,'” Al-Monitor. February $14^{\text {th }} 2013$.http://www.al-monitor.com/pulse/originals/2013/02/jordan-kingabdullah-ii-white-revolution.html; Habib Toumi, "Qatar to Hold Parliamentary Elections in 2013," Gulf News. $1^{\text {st }}$ November 2011. http://gulfnews.com/news/gulf/qatar/qatar-to-hold-parliamentary-elections-in-20131.921954; Peter Salisbury, "Insulting the Sultan," Foreign Policy, October 19th 2012. http://foreignpolicy.com/2012/10/19/insulting-the-sultan-in-oman/; Ahmed Al Omran, "Saudi Activists Silenced and the U.S. is Silent," Foreign Policy. March $11^{\text {th }}$ 2013. http://foreignpolicy.com/2013/03/11/saudi-activists-silenced-and-the-u-s-issilent/; Lori Plotkin Boghardt, "The Muslim Brotherhood on Trial in the UAE," Washington Institute for Near East Policy. April $12^{\text {th } 2013 . h t t p: / / w w w . w a s h i n g t o n i n s t i t u t e . o r g / p o l i c y-a n a l y s i s / v i e w / t h e-m u s l i m-~}$ brotherhood-on-trial-in-the-uae

30 Rosiny,“The Arab Spring: Triggers, Dynamics and Prospects,”. 2012. Op. cit. 10.

31 ibid., 13.

32 Ghaith Al-Qudah, Head of IAF Youth Sector, Interview by Jacob Amis. August 25 $5^{\text {th }}$ 2011. Amman.

33 Hayat Al-Missaymi, IAF Shura Council. Quoted by Jacob Amis, December $18^{\text {th }}$ 2011. Amman.

34 Dima Tahboub, IAF Shura Council. Interview by Jacob Amis. December 11 2011 . Amman. 
35 EydaMutlaq, Quoted by Jacob Amis. IAF Shura Council and Head of Women's Sector. December $15^{\text {th }}$ 2011. Amman.

36 Ruhayil Gharaibeh, Muslim Brotherhood Shura Council and Head of IAF Political Office. Interview by Lynch. October $3^{\text {rd }} 2011$. Amman.

37 Islamic Action Front Website, 2011. http://www.jabha.net/

38 Shadi Hamid, "Jordan: The Myth of the Democratizing Monarchy," In The Struggle over Democracy in the Middle East, eds., Nathan Brown and Emad El-Din Shahin, (New York NY: Routledge, 2010), 128.

39 Marina Ottoway and Muasher Marwan, 2011. "Arab Monarchies: Chance for Reform Yet Unmet,"Carnegie Endowment for International Peace, December 2011. http://carnegieendowment.org/files/arab_monarchies1.pdf

40 Zaki Bani Irsheid, Muslim Brotherhood Deputy General Supervisor, Interview by Jacob Amis. December $20^{\text {th }}$ 2011. Amman.

41 Gharaibeh, Interview by Lynch, 2011. Op cit.17.

42 Ibid.

43 Nimr Al-Assaf, IAF Deputy Secretary General.Interview by Jacob Amis, December $12^{\text {th }}$ 2011. Amman.

44 Jacob Amis, "The Jordanian Brotherhood in the Arab Spring," in Current Trends in Islamist Ideology, Volume 14, (2013): 38-57.

$45 \quad$ Islamic Action Front Website, Op. cit.18.

46 Muhammad Abu Rumman, "The Muslim Brotherhood after the Boycott of Parliamentary Elections of 2010," In Center for Strategic Studies Papers, (Arabic).

47 Hayat Al-Missaymi, Quoted by Jacob Amis, 2011. Op. cit. 17.

48 Hamam Sa'id, Jordan Muslim Brotherhood Website, August $21^{\text {st }} 2011$. http://www.ikhwan-jor.com/

49 Ghaith Al-Qudah, Interview by Jacob Amis, 2011. Op. cit 17.

50 BBC News. "Jordan: Man Dies in Hospital after Amman Clashes," BBC News, March 25 ${ }^{\text {th }}$ 2011.http://www.bbc.com/news/world-middle-east-12866531

51 Taylor Luck, "Mafraq Clashes Place Islamists, Govt at Crossroads," Jordan Times. December $27^{\text {th }} 2011$.

52 Ghaith Al-Qudah, Interview by Jacob Amis. 2011. Op. cit 17.

53 Gharaibeh, Interview by Lynch, 2011. Op. cit 17.

54 Ghaith Al-Qudah, Interview by Jacob Amis, 2011. Op. cit 17.

55 Roxana Apalaghie, "Plausible and Implausible Aspects of Jordan's Protests," Middle East Political and Economic Institute, September 30, 2011. http://mepei.com/infocus/5397-plausible-and-implausible-aspects-of-jordans-protests

56 Marwan Muasher, "Jordan's Proposed Constitutional Amendments--A First Step in the Right Direction," Carnegie Endowment for International Peace, August $17^{\text {th }}$ 2011. http://carnegieendowment.org/2011/08/17/jordan-s-proposed-constitutionalamendments-first-step-in-right-direction

57 Muslim Brotherhood Website, 2011. http://www.ikhwan-jor.com/

58 Ibid.

59 Shadi Hamid and Courtney Freer, "How Stable Is Jordan? King Abdullah's Halfhearted Reforms and the Challenge of the Arab Spring," Brookings Doha Center Publications, No. 8 of 47. (2011)http://www.brookings.edu/research/papers/2011/11/jordan-hamid-freer

60 Taylor Dewey, et al. "The Impact of Social Media on Social Unrest in the Arab Spring," Defense Intelligence Agency Final Report, Stanford University, 2012. https://publicpolicy.stanford.edu/publications/impact-social-media-social-unrestarab-spring 


\section{Selected Bibliography}

1. Abu Rumman, Muhammad. "The Muslim Brotherhood after the Boycott of Parliamentary Elections of 2010.” In Center for Strategic Studies Papers. (Arabic). 2011.

2. Al Omran, Ahmed. "Saudi Activists Silenced and the U.S. is Silent." Foreign Policy. March $11^{\text {th }}$ 2013. http://foreignpolicy.com/2013/03/11/saudi-activists-silenced-andthe-u-s-is-silent/

3. Al-Assaf, Nimr. IAF Deputy Secretary General. Interview by Jacob Amis, December $12^{\text {th }}$ 2011. Amman.

4. Al-Missaymi, Hayat. IAF Shura Council. Quoted by Jacob Amis, December $18^{\text {th }}$ 2011. Amman.

5. Almond, G. A., \& Verba, S. The Civic Culture; Political Attitudes and Democracy in Five Nations. Princeton, New Jersey: Princeton University Press, 1963.

6. Al-Qudah, Ghaith. Head of IAF Youth Sector, Interview by Jacob Amis. August $25^{\text {th }}$ 2011. Amman.

7. Alsoudi, Abdelmahdi. "Islam and Democracy in the Arab World." International Journal of the Humanities, Volume 1, 2003. Article: HC03-0126-2003. (English).

8. Alsoudi, Abdelmahdi. "The Impact of US Aid Policy on Democracy and Political Reform in the Arab World." International Journal of the Humanities. 2007. 4(10): 113-126.

9. Amis, Jacob. "The Jordanian Brotherhood in the Arab Spring." Current Trends in Islamist Ideology. Volume 14, (2013): 38-57.

10. Apalaghie, Roxana. "Plausible and Implausible Aspects of Jordan's Protests." Middle East Political and Economic Institute, September 30,

2011. http://mepei.com/in-focus/5397-plausible-and-implausible-aspects-of-jordansprotests

11. Ayubi, Nazih. Political Islam: Religion and Politics in the Arab World. London: Rutledge, 1991.

12. Bani Irsheid, Zaki. "Muslim Brotherhood Deputy General Supervisor." Interview by Jacob Amis. December $20^{\text {th }}$ 2011. Amman.

13. Beinin, Joel and Vairel, Frederic. Social Movements, Mobilization, and Contestation in the Middle East and North Africa (Stanford Studies in Middle Eastern and Islamic Societies and Cultures). Second Edition. California: Stanford University Press, 2013.

14. Bevington Douglass, and Dixon Chris. "Movement-relevant Theory: Rethinking Social Movement Scholarship and Activism." Social Movement Studies: Journal of Social, Cultural and Political Protest. 4(3), (2005):185-208.

15. Boghardt, Lori Plotkin. "The Muslim Brotherhood on Trial in the UAE." Washington Institute for Near East Policy. April $12^{\text {th }} 2013$.

http://www.washingtoninstitute.org/policy-analysis/view/the-muslim-brotherhoodon-trial-in-the-uae

16. Bokhari, Kamran and Senzai, Farid. Political Islam in the Age of Democratization. London: Palgrave Macmillan, 2013.

17. Burgat, Francois. Face to Face with Political Islam. New York: IB Tauris and Co. Ltd, 2003.

18. Christiansen, Jonathan. "Four Stages of Social Movements." EBSCO Publishing Inc. 2009.https://www.ebscohost.com/uploads/imported/thisTopic-dbTopic-1248.pdf

19. Da'na, Seif. "Islamic Resistance in Palestine: Hamas, the Gaza War and the Future of Political Islam." Holy Land Studies.8.2 (2009): 211-228. 
20. Dahl, Robert. A. Polyarchy; Participation and Opposition. New Haven: Yale University Press, 1972.

21. Dewey, Taylor, et al. "The Impact of Social Media on Social Unrest in the Arab Spring." Defense Intelligence Agency Final Report. Stanford University. 2012. https://publicpolicy.stanford.edu/publications/impact-social-media-social-unrestarab-spring

22. Diamond, Larry. Linz. Juan, J. and Lipset, Seymour. Martin. (Eds.) Democracy in Developing Countries (Vol. 4).Boulder, CO: Lynne Rienner, 1989.

23. Eickelman, Dale. F. and Piscatori, James. Muslim Politics (Princeton Studies in Muslim Politics). Princeton, New Jersey: Princeton University Press, 2004.

24. El Hassane, Aissa. "The Arab Spring: Causes, Consequences, and Implications." Strategy Research Project. U.S. Army War College. 2012. www.dtic.mil/cgibin/GetTRDoc?AD=ADA560779

25. Esposito, John L. "Islam and Secularism in the $20^{\text {th }}$ First Century." In Islam and Secularism in the Middle East. Edts. Esposito John. L. and Tamimi, Azzam. New York University Press, 2000.

26. Esposito, John L., \&Voll, John O. Islam and Democracy. New York: Oxford University Press, 1996.

27. Fukuyama, Francis. The End of History and the Last Man. New York: The Free Press, Macmillan Inc., 1992.

28. Gamson, William A. The Strategy of Social Protest. Second Edition. Belmont, CA: Wadsworth Publishing, 1990.

29. Gause III, F. Gregory, Saudi Arabia in the New Middle East. Washington D.C.: Council on Foreign Relations. Council Special Report No. 63, 2011.

30. Gerges, Fawaz. Contentious Politics in the Middle East: Popular Resistance and Marginalized Activism beyond the Arab Uprisings. London: Palgrave Macmillan, 2015.

31. Gharaibeh, Ruhayil. "Muslim Brotherhood Shura Council and Head of IAF Political Office." Interview by Lynch. October $3^{\text {rd }}, 2011$. Amman.

32. Greenfield, Danya. "Jordan King Launches 'White Revolution." In Al-Monitor. February $14^{\text {th }} 2013$. http://www.al-monitor.com/pulse/originals/2013/02/jordan-kingabdullah-ii-white-revolution.html

33. Haggard, Stephan. and Kaufman, Robert. R. "Inequality and Regime Change: Democratic Transitions and the Stability of Democratic Rule." American Political Science Review. 106(03), (2012):495-516.

34. Hamid, Shadi and Freer, Courtney. "How Stable Is Jordan? King Abdullah's Halfhearted Reforms and the Challenge of the Arab Spring." Brookings Doha Center Publications. No. 8 of 47.2012. http://www.brookings.edu/research/papers/2011/11/jordan-hamid-freer

35. Hamid, Shadi. "Jordan: The Myth of the Democratizing Monarchy." In The Struggle over Democracy in the Middle East. Edited by Nathan Brown and Emad El-Din Shahin. New York NY: Routledge, 2010.

36. Howard, Philip N., and Muzammil M. Hussain, "The Role of Digital Media." Journal of Democracy. 22(3), (2011): 35-48.

37. Hroub, Khaled. Eds., Political Islam: Context versus Ideology (SOAS Middle East Issues). London: SAQI, 2010.

38. Huntington, Samuel P. The Third Wave: Democratization in the Late Twentieth Century, USA: University of Oklahoma Press, 1993.

39. Huntington, Samuel. P. The Clash of Civilization and the Remaking of the New World Order. Touchstone, New York: Simon and Schuster, 1996. 
40. Inglehart, Ronald. "Values, Ideology, and Cognitive Mobilization in New Social Movements." In Challenging the Political Order: New Social and Political Movements in Western Democracies. Edts. R. J. Dalton \& M. Keuchler, New York: Oxford University Press, 1990.

41. Inglehart, Ronald. And Norris, Pippa. Rising Tide: Gender Equality and Cultural Change Around the World. Cambridge, UK; New York: Cambridge University Press. 2003.

42. Ismail, Salwa. Rethinking Islamist Politics: Culture, the State and Islamism. New York: IB Tauris and Co. Ltd., 2006.

43. Jenkins, J. Craig. "Resource Mobilization Theory and the Study of Social Movements." Annual Reviews Inc. Ann. Rev. Social, 9, (1983): 527-53.

44. Kamrava, Mehran. "The Arab Spring and the Saudi-Lead Counterrevolution”.Orbis 56.1 (2012): 96-104.

45. Lewis, Bernard. "Islam and Liberal Democracy: A Historical Overview." Journal of Democracy. 7 (2), (1996). 52-63.

46. Lipset, Seymour. Martin. Political Man: The Social Bases of Politics. New York: Doubleday Anchor, 1963.

47. Luck, Taylor, "Mafraq Clashes Place Islamists, Gov't at Crossroads." Jordan Times. December $27^{\text {th }} 2011$.

48. Lynch, Sean. "The Arab Spring: Understanding the Success of Protest through Social Movement." Washington Research Library Consortium. 2013 http://aladinrc.wrlc.org/bitstream/handle/1961/15059/Lynch,\%20Sean\%20$\% 20$ Spring\%202013.pdf? sequence $=1$

49. Marx, Karland Engels, Frederick. Selected Works in One Volume. New York: International Publishers, 1968.

50. McAdam, Doug. McCarthy, John. D. and Zald, Mayer. N. Comparative Perspectives on Social Movements: Political Opportunities, Mobilizing Structures, and Cultural Framing. New York: Cambridge University Press, 1996.

51. McAdam, Doug. Sidney Tarrow. and Charles Tilly. Dynamics of Contention. New York: Cambridge University Press, 2001.

52. McCarthy, John. D. \& Zald, Mayer. N. "Resource Mobilization and Social Movements: A Partial Theory." American Journal of Sociology. (82), (1977): 121241.

53. McCurdy Patrick. "Social Movements, Protest and Mainstream Media." Sociology Compass. 6(3), (2012): 244-255.

54. Moussalli, Ahmad., The Dialectics of Shura and Democracy: Democracy and Human Rights in the Islamic Thought. Beirut: Center of Arab Unit Studies (Arabic), 2007.

55. Muasher, Marwan. "Jordan's Proposed Constitutional Amendments--A First Step in the Right Direction." Carnegie Endowment for International Peace. August $17^{\text {th }}$ 2011. http://carnegieendowment.org/2011/08/17/jordan-s-proposed-constitutionalamendments-first-step-in-right-direction

56. Norton, Augustus. Civil Society in the Middle East. New York: Brill. 1995.

57. Oberschall, Anthony. Social Conflict and Social Movements. Englewood Cliffs, N.J.: Prentice-Hall. 1973.

58. Olson, Mancur. The Logic of Collective Action; Public Goods and the Theory of Groups. Cambridge, Mass: Harvard University Press. 1971.

59. Ottoway Marina. and Muasher Marwan. "Arab Monarchies: Chance for Reform,Yet Unmet."Carnegie Endowment for International Peace. December 2011. http://carnegieendowment.org/files/arab_monarchies1.pdf 
60. Rosiny, Stephan. "The Arab Spring: Triggers, Dynamics and Prospects." German Institute of Global and Area Studies. GIGA Focus. No. $1 / 2012$.

61. Sa'id, Hamam. Jordan Muslim Brotherhood Website. August $21^{\text {st }} 2011$. http://www.ikhwan-jor.com/

62. Sadiki, Larbi. Rethinking Arab Democratization: Elections without Democracy. New York: Oxford University Press, 2009.

63. Salisbury, Peter. "Insulting the Sultan.” Foreign Policy, October 19th 2012. http://foreignpolicy.com/2012/10/19/insulting-the-sultan-in-oman/

64. Schiller, T. "Tunisia-A Revolution and Its Consequences." KAS International Reports. 5 (2011): 6-19.

65. Schwedler, Jillian. "The Politics of Protest in Jordan." Foreign Policy Research Institute. February 2012.http://www.fpri.org/articles/2012/03/politics-protest-jordan

66. Sedra, Kamal. "The Role of Social Media \&Networking in Post-Conflict Settings: Lessons Learned from Egypt." The World Bank/TDRP, June 5-6 ${ }^{\text {th }} 2013$. http://www.tdrp.net/PDFs/Social\%20Media\%20\&\%20Arab\%20Spring\%20\%20Egypt.pdf

67. Silverstein, Paul. "Weighing Morocco's New Constitution." Middle East Research and Information Project. July $5^{\text {th }} 2011$. http://www.merip.org/mero/mero070511

68. Tarrow, Sidney and Tilly, Charles. "Contentious Politics and Social Movements."Oxford Handbook of Comparative Politics. July 2009. DOI: 10.1093/oxfordhb/9780199566020.003.0019

69. Tarrow, Sidney G. Power in Movement: Social Movements and Contentious Politics. (Cambridge Studies in Comparative Politics). Third Edition. New York: Cambridge University Press. 2011.

70. Tilly, Charles. and Wood, Lesley. Social Movements 1768-2012. Third Edition. Boulder, Co: Paradigm Publishers, 2012.

71. Tilly, Charles. Contentious Performances. New York: Cambridge University Press. 2008.

72. Tilly, Charles. From Mobilization to Revolution. Reading, MA: Addison-Wesley, 1978.

73. Toumi, Habib. "Qatar to Hold Parliamentary Elections in 2013.”Gulf News.

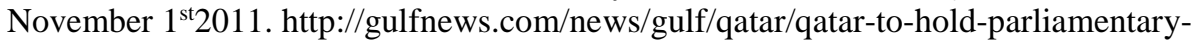
elections-in-2013-1.921954

74. Wilson, John. Introduction to Social Movements. First Edition. New York: Basic Books, 1973. 